\title{
Emerging therapeutic strategies to enhance HDL function
}

Santiago Redondo ${ }^{1,2^{*}}$, José Martínez-González ${ }^{3}$, Concha Urraca ${ }^{1}$ and Teresa Tejerina ${ }^{1}$

\begin{abstract}
Epidemiologic studies indicate a strong inverse correlation between plasma levels of high-density lipoproteins $(\mathrm{HDL})$ and cardiovascular disease (CVD). The most relevant cardioprotective mechanism mediated by HDL is thought to be reverse cholesterol transport (RCT). New insights in HDL biology and RCT have allowed the development of promising agents aimed to increase HDL function and promote atherosclerosis regression. In this regard, apo-Al analogs and CETP inhibitors dalcetrapib and anacetrapib have aroused a great interest and opened new expectations in the treatment of CVD.
\end{abstract}

\section{Introduction}

Low levels of high-density lipoproteins (HDL) are among the strongest, statistically independent risk factors for cardiovascular disease (CVD). It has been estimated that a $1 \mathrm{mg} / \mathrm{dL}$ increase of HDL-cholesterol in plasma results in a 2-3\% decrease in CVD risk [1]. The most widely accepted mechanism for this HDL protective effect is the reverse cholesterol transport (RCT). RCT refers to the mechanism by which cholesterol excess is transported from cells of extrahepatic tissues and carried back to the liver, where it can be eliminated or recycled. There has been a rising interest in the physiology and pharmacology of RCT [2]. However, contrary to what has been achieved in the field of LDL control through statin therapy, pharmacological modulation of HDL biology has not achieved a comparable success in the clinical arena. Nevertheless, this growing burden of knowledge has yielded a new generation of drugs which are under clinical evaluation and are able not only to increase HDL levels and function, but also to achieve a measurable atherosclerotic plaque regression. Within these drugs, apo-AI Milano analogs and CETP (Cholesterol ester transfer protein) inhibitors dalcetrapib and anacetrapib deserve to be highlighted according to the state-of-the-art clinical evidence.

\footnotetext{
* Correspondence: santiredondo@hotmail.com

'Department of Pharmacology, School of Medicine, Universidad

Complutense de Madrid, Spain

Full list of author information is available at the end of the article
}

\section{Reverse cholesterol transport (RCT)}

Early in the 80's it was demonstrated that HDL can act as an acceptor of cellular cholesterol, the first step in the pathway known as RCT [3]. Briefly, HDL precursors (lipid-free apoA-I or lipid-poor pre- $\beta_{1}-\mathrm{HDL}$ ) are produced by the liver, the intestine or are released from lipolysed VLDL and chylomicrons. PLTP (Phospholipid transfer protein)-mediated phospholipid transfer facilitates apo-AI lipidation and the formation of pre- $\beta$-HDL [2]. Lecithin cholesterol acyl-transferase (LCAT) esterifies cholesterol in HDL [4]. Cholesterol esters, more hydrophobic than free cholesterol, move into the core of HDL particle, creating a gradient that enables HDL to accept free cholesterol. After scavenging cholesterol from peripheral tissues, HDL transports cholesterol to the liver where it will be excreted or recycled. The selective uptake of cholesterol esters from HDL into hepatocytes is mediated by the scavenger receptor B type I (SR-BI) [2], and facilitated by the ATP binding cassette $(\mathrm{ABC})$ transporters $\mathrm{ABCA1}$ and ABCG1 [4]. However, cholesterol esters may also be transferred from HDL to other lipoproteins, including chylomicrons, VLDL and LDL, a process mediated by the CETP. Therefore, CETP possesses a potential atherogenic role by enhancing the transfer of cholesterol esters from antiatherogenic lipoproteins (HDL) to proaterogenic ones (mainly LDL). A summary of HDL regulation is shown in the Figure 1.

\section{Effects of HDL}

Antiatherosclerotic effects of $\mathrm{HDL}$

Atheromatous plaques are not irreversible lesions. Indeed, pioneer experimental studies have demonstrated

\section{() Biomed Central}




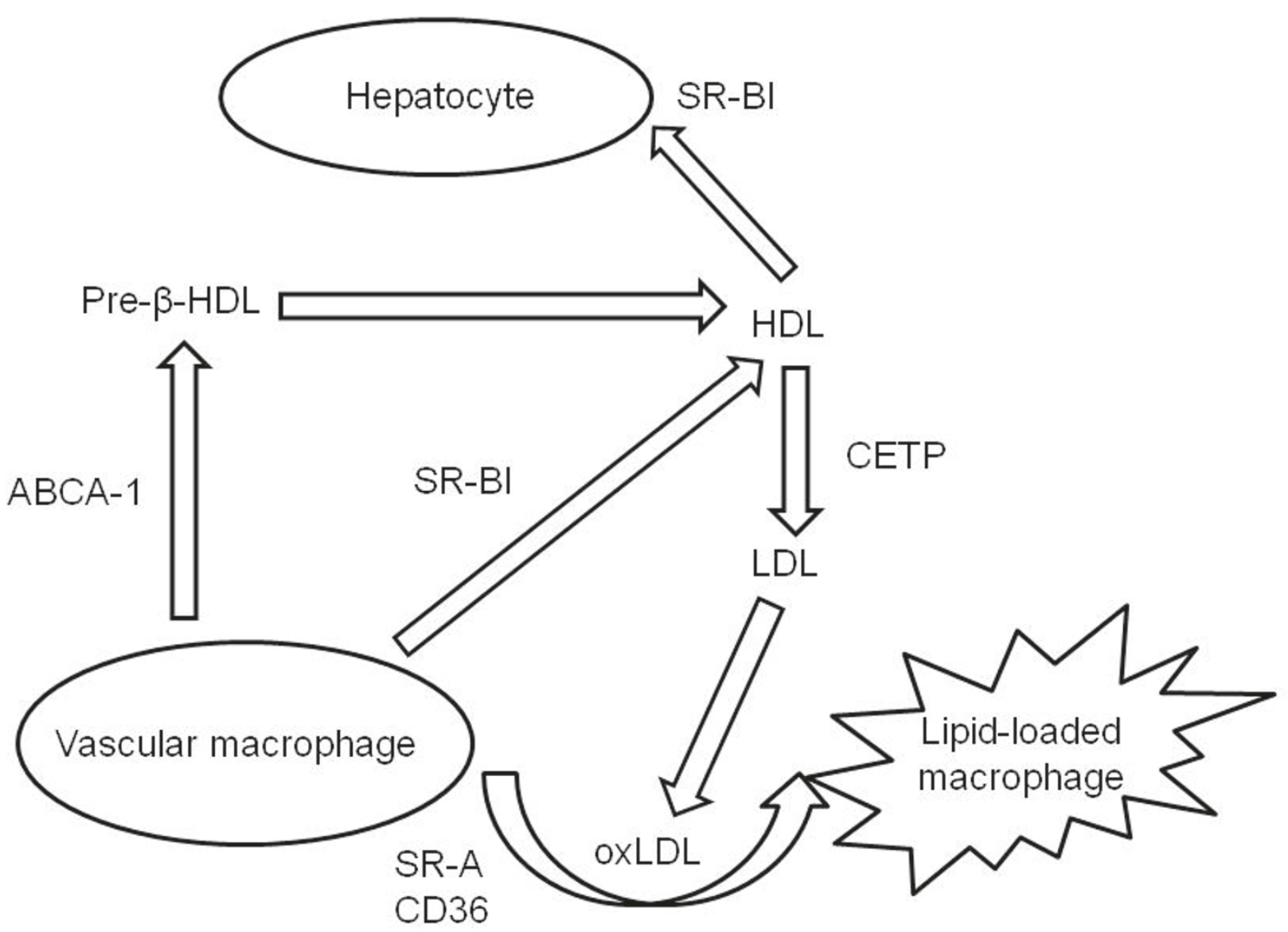

Figure 1 Simplified scheme of reverse cholesterol transport. In the onset and progression of atherosclerotic lesions the uptake of modified LDL (mainly oxidized LDL or oxLDL) by macrophages through a process mediated by scavenger receptors (i.e. SR-A and CD36) that lead to the formation of lipid-loaded cells is critical. This seems to be a reversible process, as HDL-mediated RCT can clear cholesterol from vascular tissues contributing to atherosclerosis regression. HDL acquires cholesterol through a mechanism that involves the receptor SR-BI and transports this cholesterol back to the liver. However, HDL also exchanges lipids with LDL, a process mediated by the CETP that increases LDL cholesterol cargo and potentially enhances their atherogenicity.

that HDL administration inhibits development of fatty streaks and induces regression of atherosclerotic lesions in cholesterol-fed rabbits [5,6]. Nowadays the global burden of atheromatous plaques can be measured by novel image techniques. This technology has made it possible to demonstrate that in animal models atherosclerotic plaques are reduced when HDL function is enhanced [7], and that pharmacologic treatments that modulate lipid profile (enhance HDL and decrease LDL) are able to reduce atherosclerosis progression in humans [8].

Given the central role of HDL in RCT, HDL is considered essential in therapeutic strategies aimed to inhibit/regress atherosclerotic lesions [2]. HDL can, therefore, deplete atherosclerotic plaques through their ability to promote efflux of cholesterol from lipid-loaded macrophages [9]. However, HDL is a complex macromolecule containing diverse bioactive lipids and a variety of apolipoproteins and enzymes that could individually contribute to specific antiatherogenic effects [10]. These effects are briefly reviewed in the following sections.

\section{Anti-inflammatory effects of HDL}

Numerous studies suggest that the anti-atherogenic effects of HDL are also related to their anti-inflammatory properties $[10,11]$. For instance, in macrophages, HDL prevents the conversion of progranulin into proinflammatory granulins [12]; while in endothelial cells, HDL inhibits the expression of cell adhesion molecules VCAM-1, ICAM-1 and E-selectin [13,14]. In animal models, HDL reduces leukocyte homing to arterial endothelium [15], and increased HDL levels have been associated with a decrease of the blood concentration of proinflammatory molecules both in animal models and in patients $[16,17]$. 


\section{Antioxidant effects of HDL}

HDL lipoproteins are able to counteract LDL oxidation, which is commonly considered a key event in atherogenesis. HDL inhibits the enzymatic and non-enzimatic oxidation of LDL, and exerts indirect antioxidant effects acting as a "sink" for oxidized products that come from oxidized LDL and transport them to the liver [18]. The antioxidant properties of HDL are attributed not only to apoA-I, the most abundant protein in HDL, but also to several enzymes including paraoxonase (PON), plateletactivating factor acetylhydrolase (PAF-AH) and glutation peroxidase (GPx) [19].

\section{Antithrombotic effect of HDL}

Deregulation of haemostasis plays a key role in acute coronary syndromes. Tissue factor activates the extrinsic coagulation pathway and is essential in atheromatous plaque rupture. HDL is able to reduce thrombin-induced tissue factor expression in endothelial cells [20], to inhibit platelet activation [21], and to stimulate the activation of the anticoagulant proteins $\mathrm{C}$ and $\mathrm{S}$ [22].

HDL increases the release of two major antiatherogenic/antithrombotic molecules by vascular cells: nitric oxide (NO) and prostacyclin [23]. HDL not only prevents the inhibition of endothelial nitric oxide synthase (eNOS) by oxLDL [24], but also induces per se eNOS [25] leading to the increase in NO production by the endothelium.

\section{Emerging strategies to increase HDL: apo-Al Milano and CETP inhibition \\ Genetics of HDL: apo-AI Milano}

Apo-AI Milano is a naturally occurring mutant of apo-AI first described in 1980 [26]. Paradoxically, carriers of this mutation have very low HDL cholesterol levels, but no increase in the risk of heart disease. In apo-AI Milano arginine in position 173 has been substituted by cysteine. This extra cysteine confers the capacity to form disulfide bonds yielding homodimers and heterodimers with apoAI [27]. Several studies in rabbits that received recombinant apo-AI Milano suggest that apo-AI Milano could increase RCT [28], although this has not been observed in mice expressing apo-AI Milano [29].

\section{CETP and cholesterol efflux to the liver}

CETP is synthesized in the liver, spleen, adipose tissue and macrophages, and circulates in plasma bound to HDL. The main function of CETP is to facilitate the transport of cholesterol esters and triglycerides among lipoproteins [2]. It collects cholesterol esters from HDL and exchanges them for triglycerides from chylomicrons, VLDL and LDL, and viceversa (Figure 1). Therefore, the net effect of CETP is proatherogenic. In fact, rare mutations leading to increased function of CETP have been linked to promote CVD [30]. On the other hand, genetic deficiency of CETP leads to marked increase in plasma levels of large HDL particles, and these HDL have enhanced ability to promote cholesterol efflux from foam cells [31]. CETP activity is also inhibited by current lipid-lowering drugs, such as statins, fibrates and niacin [32]. Thus, this molecule may be considered as an interesting therapeutical target in order to prevent cardiovascular disease. However, recent epidemiological studies seem to challenge the mainstream consideration of CETP as a proatherogenic stimulus. In two different large population-based studies, CETP mutation has been associated with greater risk of cardiovascular disease [33,34].

\section{Emerging drugs to increase HDL function Apo-Al mimetics}

When combined with phospholipids, recombinant apo-AI Milano (ETC-216) can be given in an intravenous setting. It has been shown to decrease atherosclerotic plaque size in animal models [7]. This effect has also been demonstrated in humans [35]. After five weeks of this intravenous treatment with ETC-216, patients have an increase of HDL, a remarkable decrease of atheromatous burden and a subsequent lower cardiovascular morbimortality $[36,37]$. In some of these analogs, four phenylalanine residues make a gastro-resistant molecule which enables its oral administration [38]. Notably, considerable debate still exists whether injection of wild-type Apo-AI can be as effective as this natural variant to stimulate RCT [39-41]. A brief summary on the clinical evidence of infusion of apo-AI Milano and wild-type apo-AI is shown in the Table 1.

\section{CETP inhibition}

Some CETP inhibitors have been demonstrated to possess a significant effect to increase HDL and decrease LDL (Figure 2). Torcetrapib showed an important effect in the rise of HDL in animal models and in the clinical arena. Among phase III studies, the ILLUSTRATE trial (910 patients, double-blind, randomized trial) compared torcetrapib and atorvastatin against atorvastatin alone [42]. It showed that in the highest quartile of HDL increase, a higher atherosclerotic regression measured by ultrasound was observed [42]. However, no benefit was observed in the whole cohort, and a higher rate of high blood pressure was noted in the torcetrapib group [42]. This torcetrapiblinked adverse effect was confirmed in the double-blind, randomized, ILLUMINATE trial (15067 patients, same comparative groups). In this trial, a higher overall cardiovascular mortality was noted in the torcetrapib group despite an efficient HDL increase [43]. This was related to sodium rise, potassium decrease and blood pressure increase, and therefore the study was stopped, the drug being withdrawn in the United States and the European Union [44]. Further studies linked these effects with a 
Table 1 Clinical evidence on apo-AI HDL infusion

\begin{tabular}{|c|c|c|c|}
\hline Study & Patients & Administration & Result \\
\hline $\begin{array}{l}\text { Nicholls et al., } \\
\text { [36] }\end{array}$ & 47 post-acute coronary events (randomized) & $\begin{array}{l}\text { Intravenous } \\
\text { Apo-Al Milano }\end{array}$ & 4.6\% decrease of lamina elastic interna (measured by ultrasound) \\
\hline $\begin{array}{l}\text { Nissen et al., } \\
{[37]}\end{array}$ & 123 post-acute coronary events (randomized) & $\begin{array}{l}\text { Intravenous } \\
\text { Apo-Al Milano }\end{array}$ & $4.2 \%$ decrease of atheromatous plaque volume (measured by ultrasound) \\
\hline $\begin{array}{l}\text { Tardif et al., } \\
{[40]}\end{array}$ & 183 patients on coronariography (randomized) & $\begin{array}{l}\text { Intravenous } \\
\text { reconstituted wild-type HDL }\end{array}$ & $\begin{array}{l}\text { 3.4\% decrease of plaque volume (measured by ultrasound) at follow-up(not } \\
\text { difference at baseline) }\end{array}$ \\
\hline $\begin{array}{l}\text { Shaw et al., } \\
\text { [41] }\end{array}$ & $\begin{array}{l}20 \text { patients with claudication who underwent femoral } \\
\text { endarterectomy (randomized) }\end{array}$ & $\begin{array}{l}\text { Intravenous reconstituted wild- } \\
\text { type HDL }\end{array}$ & $\begin{array}{l}\text { Decreased expression of vascular cell adhesion molecule-1 and decreased lipid } \\
\text { content }\end{array}$ \\
\hline
\end{tabular}




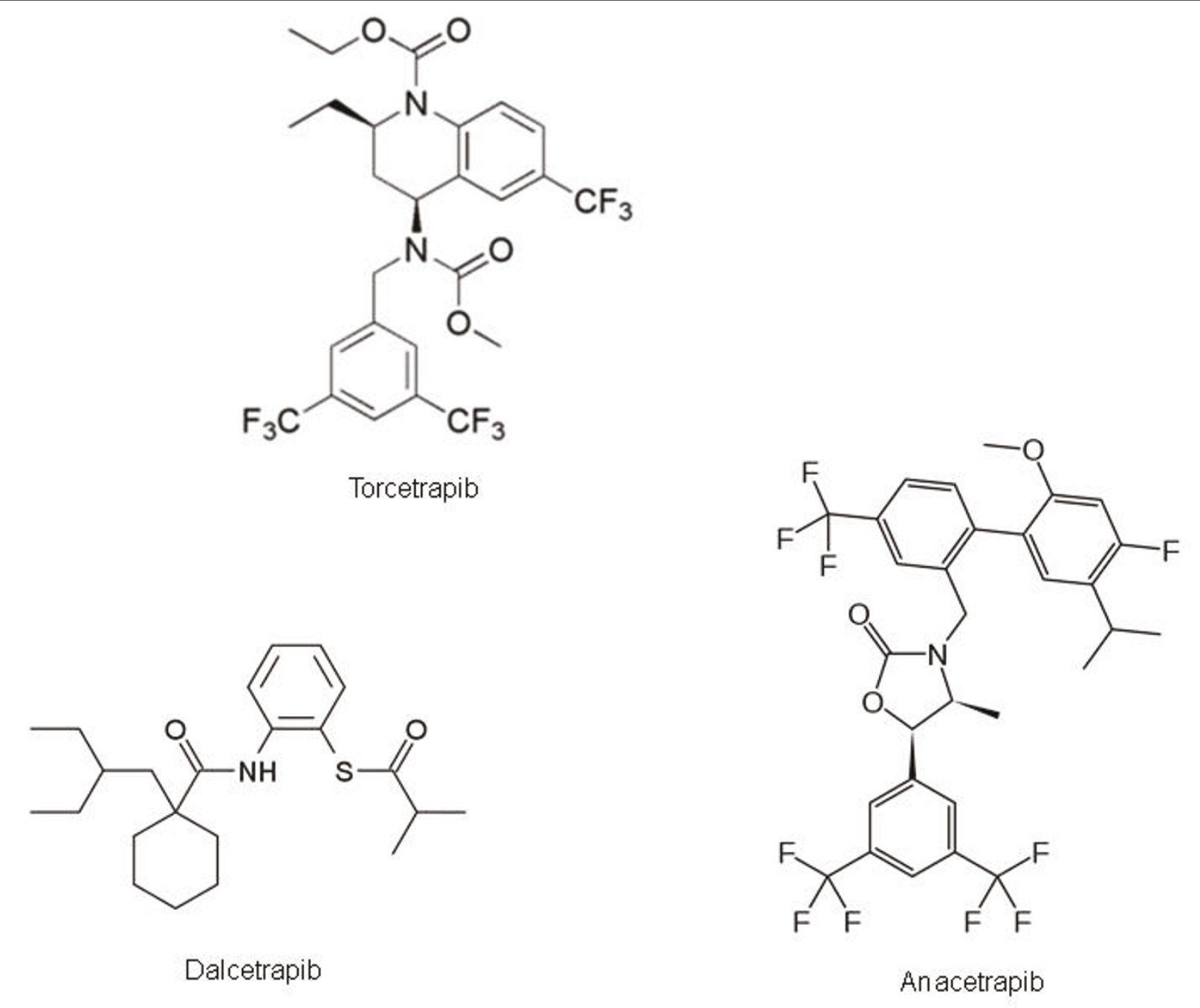

Figure 2 Chemical structure of torcetrapib, dalcetrapib and anacetrapib.

torcetrapib-mediated increase in mineralocorticoid stimulation [45]. However, this effect is not mediated by CETP inhibition and therefore is not necessarily shared by other CETP blockers. Therefore, the role of CETP inhibitors dalcetrapib [46] and anacetrapib [47] is being evaluated, given that they seem to increase HDL without the adverse effect in blood pressure. Ongoing big phase III will eventually show the potential of these promising drugs.

Dalcetrapib (Figure 2) offers the advantage of a high pharmacological potency, having $0.4-10 \mu \mathrm{M} \mathrm{IC} \mathrm{I}_{50}$ for the inhibition of CETP (compared to $19-79 \mu \mathrm{M}$ of torcetrapib). Dalcetrapib is highly specific for the interaction of cysteine 13 from CETP [32]. Preclinical animal models showed its capability to increase HDL without a significant increase in blood pressure [48]. Further clinical trials demonstrated that it does not possess hypertensive effect in humans and strengthened the idea that dalcetrapib rises HDL without any significant increase in blood pressure
$[46,49]$. Large phase III trials are still ongoing with this drug. The dal-VESSEL trial will assess the effect of dalcetrapib in the reduction of atheromatous plaques measured by PET/TAC and MRI [32]. The dal-OUTCOMES trial will evaluate the effect of the drug on the cardiovascular morbimortality of a sample of 15600 high-risk patients [32].

Anacetrapib (Figure 2) is another CETP inhibitor. It has an $\mathrm{IC}_{50}$ of 15-57 $\mu \mathrm{M}$ [32]. Its capability to raise HDL without a parallel increase of blood pressure has been demonstrated in phase I trials [50]. A broader study (589 patients) showed that treatment of anacetrapib and atorvastatin $20 \mathrm{mg}$ increased HDL [51]. Anacetrapib, at the maximum tolerated dose of $300 \mathrm{mg}$, is able to increase HDL and decrease LDL. However, this last effect is notably enhanced when given with statins, reaching a $70 \%$ reduction, without any increase in blood pressure [51]. Based on this synergism strategy, the DEFINE trial will 
evaluate the role of anacetrapib on 1623 patients whose statin treatment has achieved LDL $<100 \mathrm{mg} / \mathrm{dl}$, but having $\mathrm{HDL}<60 \mathrm{mg} / \mathrm{dl}[32]$.

\section{Liver $\times$ Receptor (LXR) agonists}

There are two LXR isoforms: LXR $\beta$, ubiquitously expressed, and LXR $\alpha$ distributed in a tissue-specific fashion, but mainly in liver and tissues involved in lipid metabolism. LXRs are activated by specific oxidized forms of cholesterol (oxysterols) such as 24(S)-hydroxycholesterol and by certain intermediates of the cholesterol biosynthesis. Analysis of LXR-deficient mice has revealed a broad role of this receptor in the regulation of genes involved in lipid homeostasis [52]. For instance, in mice LXR agonists reduce cholesterol absorption in the intestine due to the up-regulation of ABCG5 and ABCG8, which increase the efflux of cholesterol thereby limiting its absoption by intestinal cells [53]. Most interestingly, ABCA1, a key transporter in the efflux of cholesterol and phospholipids from macrophages, is a direct target of LXR [54]. In fact, treatment with endogenous LXR agonists is able to increase the RCT from macrophages and foam cells and thus increase the biliary excretion of this lipid [55]. At the same time, synthetic LXR agonists are able to prevent atheromatous plaque formation in mice [56]. However, these drugs promote the expression of lipogenic genes in the liver, which increase the levels of triglycerides and promote hepatic steatosis [57]. For this reason, research on more selective LXR ligands is an active field of experimental pharmacology.

\section{Scavenger receptor B-1 (SR-BI) inhibitors}

$\mathrm{SR}-\mathrm{BI}$ is a receptor which modulates the hepatic uptake of cholesterol esters by HDL, VLDL and native LDL. Mice without SR-BI have increased LDL levels and are prone to atherosclerosis [58]. However, in humans SRBI blockade by ITX5061, a molecule initially characterized as a p38 mitogen-activated protein kinase (MAPK) inhibitor, increases HDL, although this effect seems to be very transient [59].

\section{Summary}

RCT is thought to be one of the most important HDLmediated cardioprotective mechanisms. However, contrary to what has been achieved with LDL modulation by statin treatment, this mechanism has not been able to be modulated by safe and effective drugs to date. In fact, the beneficial therapeutic effects of raising HDL are proving difficult to confirm in humans. Recent experimental, translational and clinical research has yielded new drugs inspired, in some cases, in variants found in Nature, such as apo-AI Milano analogs, and CETP inhibitors (dalcetrapib and anacetrapib). Low HDL level is the most frequent lipoprotein abnormality in patients suffering premature
CVD. In this context, ongoing clinical studies with emerging drugs aimed to increase HDL function have aroused a great interest and opened new expectations in the treatment of CVD.

\section{Acknowledgements}

This work was supported by FISS (Health Research Fund, PI080920) and Red Tematica de Investigación Cardiovascular RECAVA (RD06/0014/1007; RD06/ 0014/0027), both from the Instituto de Salud Carlos III (ISCIII).

\section{Author details}

${ }^{1}$ Department of Pharmacology, School of Medicine, Universidad Complutense de Madrid, Spain. ${ }^{2}$ Service of Hematology, Hospital Nuestra Señora de Sonsoles, Ávila, Spain. ${ }^{3}$ Cardiovascular Research Center (CSICICCC), IIB-Sant Pau, Barcelona, Spain.

\section{Authors' contributions}

$\mathrm{CU}$ and $T$ undertook the initial review of the literature. SR and $\Pi$ conceived the idea of the manuscript. SR, CU, J M-G and TT took part in the design of the manuscript draft. SR, CU, J M-G and $T T$ built the final version. All authors read and approved the final manuscript.

\section{Competing interests}

Santiago Redondo has given conferences and received honoraria from Gilead and Merck Sharp \& Dohme.

Received: 9 September 2011 Accepted: 10 October 2011

Published: 10 October 2011

\section{References}

1. Gordon DJ, Probstfield JL, Garrison RJ, Neaton JD, Castelli WP, Knoke JD, Jacobs DR Jr, Bangdiwala S, Tyroler HA: High-density lipoprotein cholesterol and cardiovascular disease. Four prospective American studies. Circulation 1989, 79:8-15.

2. Julve J, Llaverias G, Blanco-Vaca F, Escolà-Gil JC: Seeking novel targets for improving in vivo macrophage-specific reverse cholesterol transport: translating basic science into new therapies for the prevention and treatment of atherosclerosis. Curr Vasc Pharmacol 2011, 9:220-237.

3. Fielding CJ, Fielding PE: Cholesterol transport between cells and body fluids. Role of plasma lipoproteins and the plasma cholesterol esterification system. Med Clin North Am 1982, 66:363-373.

4. Cuchel M, Lund-Katz S, de la Llera-Moya M, Millar JS, Chang D, Fuki I, Rothblat GH, Phillips MC, Rader DJ: Pathways by which reconstituted high-density lipoprotein mobilizes free cholesterol from whole body and from macrophages. Arterioscler Thromb Vasc Biol 2010 30:526-532.

5. Badimon JJ, Badimon L, Galvez A, Dische R, Fuster V: High density lipoprotein plasma fractions inhibit aortic fatty streaks in cholesterol-fed rabbits. Lab Invest 1989, 60:455-461.

6. Badimon JJ, Badimon L, Fuster V: Regression of atherosclerotic lesions by high density lipoprotein plasma fraction in the cholesterol-fed rabbit. J Clin Invest 1990, 85:1234-1241.

7. Ibañez B, Vilahur G, Cimmino G, Speidl WS, Pinero A, Choi BG, Zafar MU, Santos-Gallego CG, Krause B, Badimon L, Fuster V, Badimon JJ: Rapid change in plaque size, composition, and molecular footprint after recombinant apolipoprotein A-I Milano (ETC-216) administration: magnetic resonance imaging study in an experimental model of atherosclerosis. J Am Coll Cardiol 2008, 51:1104-1109.

8. Lee JM, Robson MD, Yu LM, Shirodaria CC, Cunnington C, Kylintireas I Digby JE, Bannister T, Handa A, Wiesmann F, Durrington PN, Channon KM, Neubauer S, Choudhury RP: Effects of high-dose modified-release nicotinic acid on atherosclerosis and vascular function: a randomized placebo-controlled, magnetic resonance imaging study. J Am Coll Cardiol 2009, 54:1787-1794.

9. Lewis GF: Determinants of plasma HDL concentrations and reverse cholesterol transport. Curr Opin Cardiol 2006, 21:345-352.

10. Assmann G, Nofer JR: Atheroprotective effects of high-density lipoproteins. Annu Rev Med 2003, 54:321-341.

11. Barter PJ, Nicholls S, Rye KA, Anantharamaiah GM, Navab M, Fogelman AM: Antiinflammatory properties of HDL. Circ Res 2004, 95:764-772. 
12. Okura H, Yamashita S, Ohama T, Saga A, Yamamoto-Kakuta A, Hamada Y, Sougawa N, Ohyama R, Sawa Y, Matsuyama A: HDL/apolipoprotein A-I binds to macrophage-derived progranulin and suppresses its conversion into proinflammatory granulins. J Atheroscler Thromb 2010, 17:568-577.

13. Barter PJ, Baker PW, Rye KA: Effect of high-density lipoproteins on the expression of adhesion molecules in endothelial cells. Curr Opin Lipidol 2002, 13:285-288.

14. Nofer JR, Geigenmüller S, Göpfert C, Assmann G, Buddecke E, Schmidt A: High density lipoprotein-associated lysosphingolipids reduce E-selectin expression in human endothelial cells. Biochem Biophys Res Commun 2003, 310:98-103.

15. Theilmeier G, De Geest B, Van Veldhoven PP, Stengel D, Michiels C, Lox M, Landeloos M, Chapman MJ, Ninio E, Collen D, Himpens B, Holvoet P: HDLassociated PAF-AH reduces endothelial adhesiveness in apoE-/- mice. FASEB J 2000, 14:2032-2039.

16. Puranik R, Bao S, Nobecourt E, Nicholls SJ, Dusting GJ, Barter PJ, Celermajer DS, Rye KA: Low dose apolipoprotein A-I rescues carotid arteries from inflammation in vivo. Atherosclerosis 2008, 196:240-247.

17. Yamagishi S, Adachi H, Matsui T, Nakamura K, Enomoto M, Fukami A, Otsuka M, Kumagae S, Nanjo Y, Imaizumi T: Decreased high-density lipoprotein cholesterol level is an independent correlate of circulating tumor necrosis factor-alpha in a general population. Clin Cardiol 2009, 32: E29-E32.

18. Bowry WW, Stanley KK, Stocker R: High density lipoprotein is the major carrier of lipid hydroperoxides in human blood plasma from fasting donors. Proc Natl Acad Sci USA 1992, 89:10316-10320.

19. Podrez EA: Anti-oxidant properties of high-density lipoprotein and atherosclerosis. Clin Exp Pharmacol Physiol 2010, 37:719-725.

20. Viswambharan $H$, Ming XF, Zhu S, Hubsch A, Lerch $P$, Vergères $G$, Rusconi $S$, Yang Z: Reconstituted high-density lipoprotein inhibits thrombininduced endothelial tissue factor expression through inhibition of RhoA and stimulation of phosphatidylinositol 3-kinase but not Akt/endothelial nitric oxide synthase. Circ Res 2004, 94:918-925.

21. Nofer JR, Brodde MF, Kehrel BE: High-density lipoproteins, platelets and the pathogenesis of atherosclerosis. Clin Exp Pharmacol Physiol 2010, 37:726-735.

22. Griffin JH, Kojima K, Banka CL, Curtiss LK, Fernández JA: High-density lipoprotein enhancement of anticoagulant activities of plasma protein $\mathrm{S}$ and activated protein C. J Clin Invest 1999, 103:219-227.

23. Rodríguez C, González-Díez M, Badimon L, Martínez-González J: Sphingosine-1-phosphate: A bioactive lipid that confers high-density lipoprotein with vasculoprotection mediated by nitric oxide and prostacyclin. Thromb Haemost 2009, 101:665-673.

24. Uittenbogaard A, Shaul PW, Yuhanna IS, Blair A, Smart EJ: High density lipoprotein prevents oxidized low density lipoprotein-induced inhibition of endothelial nitric-oxide synthase localization and activation in caveolae. J Biol Chem 2000, 275:11278-11283.

25. Yuhanna IS, Zhu Y, Cox BE, Hahner LD, Osborne-Lawrence S, Lu P, Marcel YL, Anderson RG, Mendelsohn ME, Hobbs HH, Shaul PW: Highdensity lipoprotein binding to scavenger receptor-BI activates endothelial nitric oxide synthase. Nat Med 2001, 7:853-857.

26. Franceschini G, Sirtori CR, Capurso A, Weisgraber KH, Mahley RW: A-IMilano apoprotein. Decreased high density lipoprotein cholesterol levels with significant lipoprotein modifications and without clinical atherosclerosis in an Italian family. J Clin Invest 1980, 66:892-900.

27. Weisgraber KH, Bersot TP, Mahley RW, Franceschini G, Magani D, Sirtori CR: Isolation and characterization of a cysteine-containing variant of the apoprotein A-1 from high density lipoprotein. J Clin Invest 1980, 66:901-907.

28. Cimmino G, Ibanez B, Vilahur G, Speidl WS, Fuster V, Badimon L, Badimon JJ: Up-regulation of reverse cholesterol transport key players and rescue from global inflammation by ApoA-I(Milano). J Cell Mol Med 2009, 13:3226-3235.

29. Alexander ET, Weibel GL, Joshi MR, Vedhachalam C, de la Llera-Moya M, Rothblat GH, Phillips MC, Rader DJ: Macrophage reverse cholesterol transport in mice expressing ApoA-I Milano. Arterioscler Thromb Vasc Biol 2009, 29:1496-501.

30. Zhong S, Sharp DS, Grove JS, Bruce C, Yano K, Curb JD, Tall AR: Increased coronary heart disease in Japanese-American men with mutation in the cholesteryl ester transfer protein gene despite increased HDL levels. J Clin Invest 1996, 97:2917-2923.
31. Matsuura F, Wang N, Chen W, Jiang XC, Tall AR: HDL from CETP-deficient subjects shows enhanced ability to promote cholesterol efflux from macrophages in an apoE- and ABCG1-dependent pathway. J Clin Invest 2006, 116:1435-1342

32. Chapman MJ, Le Goff W, Guerin M, Kontush A: Cholesteryl ester transfer protein: at the heart of the action of lipid-modulating therapy with statins, fibrates, niacin, and cholesteryl ester transfer protein inhibitors. Eur Heart J 2010, 31:149-164.

33. Vasan RS, Pencina MJ, Robins SJ, Zachariah JP, Kaur G, D'Agostino RB, Ordovas JM: Association of circulating cholesteryl ester transfer protein activity with incidence of cardiovascular disease in the community. Circulation 2009, 120:2414-2420.

34. Mowri HO, Patsch JR, Ritsch A, Föger B, Brown S, Patsch W: High density lipoproteins with differing apolipoproteins: relationships to postprandial lipemia, cholesteryl ester transfer protein, and activities of lipoprotein lipase, hepatic lipase, and lecithin: cholesterol acyltransferase. J Lipid Res 1994, 35:291-300.

35. Nicholls SJ, Uno K, Kataoka Y, Nissen SE: ETC-216 for coronary artery disease. Expert Opin Biol Ther 2011, 11:387-394.

36. Nicholls SJ, Tuzcu EM, Sipahi I, Schoenhagen P, Crowe T, Kapadia S, Niossen SE: Relationship between atheroma regression and change in lumen size after infusion of apolipoprotein A-I Milano. J Am Coll Cardiol 2006, 47:992-997.

37. Nissen SE, Tsunoda T, Tuzcu EM, Schoenhagen P, Cooper CJ, Yasin M, Eaton GM, Lauer MA, Sheldon WS, Grines CL, Halpern S, Crowe T, Blankenship JC, Kerensky R: Effect of recombinant ApoA-I Milano on coronary atherosclerosis in patients with acute coronary syndromes: a randomized controlled trial. JAMA 2003, 290:2292-2300.

38. Navab M, Anantharamaiah GM, Hama S, Garber DW, Chaddha M, Hough G, Lallone R, Fogelman AM: Oral administration of an Apo A-I mimetic Peptide synthesized from $D$-amino acids dramatically reduces atherosclerosis in mice independent of plasma cholesterol. Circulation 2002, 105:290-292

39. Weibel GL, Alexander ET, Joshi MR, Rader DJ, Lund-Katz S, Phillips MC Rothblat GH: Wild-type ApoA-I and the Milano variant have similar abilities to stimulate cellular lipid mobilization and efflux. Arterioscler Thromb Vasc Biol 2007, 27:2022-2029.

40. Tardif JC, Grégoire J, L'Allier PL, Ibrahim R, Lespérance J, Heinonen TM, Kouz S, Berry C, Basser R, Lavoie MA, Guertin MC, Rodés-Cabau J, Effect of rHDL on Atherosclerosis-Safety and Efficacy (ERASE) Investigators: Effects of reconstituted high-density lipoprotein infusions on coronary atherosclerosis: a randomized controlled trial. JAMA 2007, 297:1675-1682.

41. Shaw JA, Bobik A, Murphy A, Kanellakis P, Blombery P, Mukhamedova N, Woollard K, Lyon S, Sviridov D, Dart AM: Infusion of reconstituted highdensity lipoprotein leads to acute changes in human atherosclerotic plaque. Circ Res 2008, 103:1084-1091.

42. Nissen SE, Tardif JC, Nicholls SJ, Revkin JH, Shear CL, Duggan WT, Ruzyllo W, Bachinsky WB, Lasala GP, Tuzcu EM, ILLUSTRATE Investigators: Effect of torcetrapib on the progression of coronary atherosclerosis. $N$ Engl J Med 2007, 356:1304-1316.

43. Barter PJ, Caulfield M, Eriksson M, Grundy SM, Kastelein JJ, Komajda M, Lopez-Sendon J, Mosca L, Tardif JC, Waters DD, Shear CL, Revkin JH, Buhr KA, Fisher MR, Tall AR, Brewer B, ILLUMINATE Investigators: Effects of torcetrapib in patients at high risk for coronary events. $N$ Engl J Med 2007, 357:2109-2122.

44. Psaty BM, Lumley T: Surrogate end points and FDA approval: a tale of 2 lipid-altering drugs. JAMA 2008, 299:1474-1476.

45. Hu X, Dietz JD, Xia C, Knight DR, Loging WT, Smith AH, Yuan H, Perry DA, Keiser J: Torcetrapib induces aldosterone and cortisol production by an intracellular calcium-mediated mechanism independently of cholesteryl ester transfer protein inhibition. Endocrinology 2009, 150:2211-2219.

46. Stein EA, Roth EM, Rhyne JM, Burgess T, Kallend D, Robinson JG: Safety and tolerability of dalcetrapib (RO4607381/JTT-705): results from a 48-week trial. Eur Heart J 2010, 31:480-488.

47. Cannon CP, Shah S, Dansky HM, Davidson M, Brinton EA, Gotto AM, Stepanavage M, Liu SX, Gibbons P, Ashraf TB, Zafarino J, Mitchel Y, Barter P, Determining the Efficacy and Tolerability Investigators: Determining the Efficacy and Tolerability Investigators: Safety of anacetrapib in patients with or at high risk for coronary heart disease. N Engl J Med 2010, 363:2406-2415 
48. Stroes ES, Kastelein JJ, Bénardeau A, Kuhlmann O, Blum D, Campos LA, Clerc RG, Nisor EJ: Dalcetrapib: no off-target toxicity on blood pressure or on genes related to the renin-angiotensin-aldosterone system in rats. $\mathrm{Br}$ J Pharmacol 2009, 158:1763-1770

49. Kuivenhoven JA, de Grooth GJ, Kawamura H, Klerkx AH, Wilhelm F, Trip MD, Katelein JJ: Effectiveness of inhibition of cholesteryl ester transfer protein by JTT-705 in combination with pravastatin in type II dyslipidemia. Am J Cardiol 2005, 95:1085-1088.

50. Krishna R, Anderson MS, Bergman AJ, Jin B, Fallon M, Cote J, Rosko K, Chavez-Eng C, Lutz R, Bloomfield DM, Gutierrez M, Doherty J, Bieberdorf F, Chodakewitz J, Gottesdiener KM, Wagner JA: Effect of the cholesteryl ester transfer protein inhibitor, anacetrapib, on lipoproteins in patients with dyslipidaemia and on 24-h ambulatory blood pressure in healthy individuals: two double-blind, randomised placebo-controlled phase I studies. Lancet 2007, 370:1907-1914.

51. Bloomfield D, Carlson GL, Sapre A, Tribble D, McKenney JM, Littlejohn TW, Sisk CM, Mitchel Y, Pasternak RC: Efficacy and safety of the cholesteryl ester transfer protein inhibitor anacetrapib as monotherapy and coadministered with atorvastatin in dyslipidemic patients. Am Heart $J$ 2009, 157:352-360.

52. Ricote M, Valledor AF, Glass CK: Decoding transcriptional programs regulated by PPARs and LXRs in the macrophage: effects on lipid homeostasis, inflammation, and atherosclerosis. Arterioscler Thromb Vasc Biol 2004, 24:230-239.

53. Yu L, York J, von Bergmann K, Lutjohann D, Cohen JC, Hobbs HH: Stimulation of cholesterol excretion by the liver $\times$ receptor agonist requires ATP-binding cassette transporters G5 and G8. J Biol Chem 2003, 278:15565-15570.

54. Venkateswaran A, Laffitte BA, Joseph SB, Mak PA, Wilpitz DC, Edwards PA, Tontonoz P: Control of cellular cholesterol efflux by the nuclear oxysterol receptor LXR alpha. Proc Natl Acad Sci USA 2000, 97:12097-12102.

55. Naik SU, Wang X, Da Silva JS, Jaye M, Macphee CH, Reilly MP, Billheimer JT, Rothblat GH, Rader DJ: Pharmacological activation of liver $\times$ receptors promotes reverse cholesterol transport in vivo. Circulation 2006 113:90-97.

56. Peng D, Hiipakka RA, Xie JT, Dai Q, Kokontis JM, Reardon CA, Getz GS, Liao S: A novel potent synthetic steroidal liver $\times$ receptor agonist lowers plasma cholesterol and triglycerides and reduces atherosclerosis in LDLR (-/-) mice. Br J Pharmacol 2011, 162:1792-1804

57. Cha JY, Repa JJ: The liver $\times$ receptor (LXR) and hepatic lipogenesis. The carbohydrate-response element-binding protein is a target gene of LXR. J Biol Chem 2007, 282:743-751.

58. Braun A, Trigatti BL, Post MJ, Sato K, Simons M, Edelberg JM, Rosenberg RD, Schrenzel M, Krieger M: Loss of SR-BI expression leads to the early onset of occlusive atherosclerotic coronary artery disease, spontaneous myocardial infarctions, severe cardiac dysfunction, and premature death in apolipoprotein E-deficient mice. Circ Res 2002, 90:270-276.

59. Masson D, Koseki M, Ishibashi M, Larson CJ, Miller SG, King BD, Tall AR Increased HDL cholesterol and apoA-I in humans and mice treated with a novel SR-BI inhibitor. Arterioscler Thromb Vasc Biol 2009, 29:2054-2060

doi:10.1186/1476-511X-10-175

Cite this article as: Redondo et al:: Emerging therapeutic strategies to enhance HDL function. Lipids in Health and Disease 2011 10:175.

\section{Submit your next manuscript to BioMed Central and take full advantage of:}

- Convenient online submission

- Thorough peer review

- No space constraints or color figure charges

- Immediate publication on acceptance

- Inclusion in PubMed, CAS, Scopus and Google Scholar

- Research which is freely available for redistribution

Submit your manuscript at www.biomedcentral.com/submit
Biomed Central 